\title{
Characteristics of crude cellulose from palm (Elaeis oleifera) midrib by sodium hydroxide pretreatment
}

\author{
${ }^{1 *}$ Ferdiansyah, M.K., ${ }^{2}$ Pranoto, Y. and ${ }^{2}$ Marseno, D.W. \\ ${ }^{1}$ Department of Food Technology, Faculty of Engineering and Informatics, Universitas PGRI Semarang, \\ Jalan Sidodadi Timur 24, Semarang, 50125, Indonesia \\ ${ }^{2}$ Department of Food Technology and Agricultural Products, Faculty of Agricultural Technology, \\ Universitas Gadjah Mada, Jalan Flora No. 1 Bulaksumur, Yogyakarta, 55281, Indonesia
}

\begin{abstract}
Article history:
Received: 11 November 2017

Received in revised form: 16 January 2018

Accepted: 23 January 2018

Available Online: 29 January 2018
\end{abstract}

\section{Keywords:}

Cellulose,

Characterization,

Extraction,

Palm midrib

DOI:

https://doi.org/10.26656/fr.2017.2(3).282

\begin{abstract}
The purpose of this research was to determine the effect of concentration of sodium hydroxide $(\mathrm{NaOH})$ on physicochemical characteristics of cellulose powder extracted from palm midrib that was underutilized optimally. Cellulose extraction was done using a solution of $\mathrm{NaOH}$ with concentrations of $9,12,15,18 \%$. Cellulose powder obtained was analyzed water content, cellulose content, yield, lightness, functional groups, and crystallinity. Cellulose powder extracted with $\mathrm{NaOH} 15 \%$ had water content $9.3 \%$ (w.b), cellulose content $89.63 \%$ (d.b), yield $37.32 \%$ (d.b), lightness value 90.83 , and crystallinity $31.57 \%$. NaOH had the ability to break lignocellulose bond so that cellulose will be free from lignin. The results of FTIR spectra analysis of commercial cellulose and cellulose from palm midrib extracted with $\mathrm{NaOH} 15 \%$ solution showed the same pattern of the functional group.
\end{abstract}

\section{Introduction}

The midrib was part of the palm oil plant that was underutilized optimally, even its presence was often regarded as a plantation waste (Ferdiansyah et al., 2017). One of the efforts that had been made to utilize palm midrib was making it as a mixture of animal feed. This utilization was still limited, in terms of application and economic value. Another alternative in terms of utilization of palm midrib was needed so that it would produce more economically valuable products and had various applications.

The process of delignification, bleaching, and purification in palm midrib sample will give white alphacellulose (Sebayang and Sembiring, 2017). From 75 grams of palm oil, midrib powder will give 19.77 grams of pure alpha-cellulose (it was assumed to be $26.36 \%$ of the initial mass). Such high levels of cellulose were a potential that palm midrib can be further processed into a product of higher economic value and useful in applications. Cellulose was a polymer that is found in the cell wall of plants. In the cell wall, cellulose was bound to other substances such as lignin and hemicellulose. To get a pure cellulose it was necessary to do the extraction process first. Cellulose could be extracted from palm midrib by extraction process using a basic $\mathrm{NaOH}$ solution. $\mathrm{NaOH}$ had the ability to disrupt the lignin structure of the biomass (Brodeur, 2011). The purpose of this research was to determine the effect of the concentration of $\mathrm{NaOH}$ on some characteristics of cellulose powder extracted from palm midrib

\section{Materials and methods}

\subsection{Materials}

Palm midrib used in the research was derived from oil palm plantation in Donomulyo District, Malang, East Java, Indonesia. $\mathrm{NaOH}$ (technical grade), aquadest, $\mathrm{NaCl}$, acetic acid, $\mathrm{NaOCl}$, and $\mathrm{Na}-$ metabisulfite were used for cellulose extraction process. Ethanol, acetic acid, $\mathrm{NaOH}$, and aquadest were used for cellulose characterization. The equipment used for the preparation of palm midrib powder were grinding machine and sieve. For the process of extraction of palm, midrib cellulose, Erlenmeyer $1 \mathrm{~L}$, and water bath equipped temperature control was used. The oven equipment, desiccators, weighing bottles, porcelain cups, furnaces (Heracus Instruments M-110), Fourier-transform infrared spectroscopy (FT-IR, Shimadzu Prestige-21), X-Ray diffractometry (XRD, Mac Science MXP3) were used for characterization.

\subsection{Preparation of palm midrib powder}

Powdering palm midrib started with cutting and 
drying of the palm midrib in dryer cabinet of $50^{\circ} \mathrm{C}$, the pieces of dried palm midrib were milled by using a grinding machine and then sieved to 60 mesh size.

\subsection{Cellulose extraction of palm midrib}

Cellulose extraction of palm midrib was extracted from the palm midrib with $\mathrm{NaOH}$ solution with several concentrations $(9,12,15,18 \%)$ temperature of $100^{\circ} \mathrm{C}$ for 3 hours that aimed to dissolve the lignin components. The solids were lagged after washing with clean water from residual of $\mathrm{NaOH}$, immersed with distilled water mixed with $\mathrm{NaCl}$ and acetic acid. Washing process and the solids were lagged could be done by bleaching with $\mathrm{NaOCl} 12 \%$ and $\mathrm{Na}$ metabisulphite of $60^{\circ} \mathrm{C}$ for 3 hours, then washed with clean water until the pulp (cellulose) obtained odorless hypochlorite. Cellulose was obtained then dried using an oven.

\subsection{Characterization of palm midrib cellulose}

Palm midrib cellulose was characterized based on the water content, yield, cellulose content, lightness, crystallinity and functional groups. Methods used for analysis were cellulose content (Browning, 1967), water content (ASTM D-1439-94 (ASTM, 1994)), lightness analysis (Rossel et al., 2009). Structural analysis was performed using FTIR and X-Ray Diffraction (Lii et al., 2002). FTIR used to functional groups analysis and XRay Diffraction used to crystallinity analysis.

\subsection{Statistical analysis}

This research used factorial design. The Data obtained were analyzed by Variant Analysis (ANOVA) followed by real difference test DMRT (Duncan Multiple Range Test) with confidence interval 5\%.

\section{Results and discussion}

\subsection{Characteristics of palm midrib powder}

This research used the main raw material, palm midrib, that had been dried and made into powder with a size of 60 mesh. The powder making process aimed to expand the surface of the material so that it will be easier in the process of cellulose extraction. The palm midrib powder was characterized to determine the cellulose content and the characteristics of the cellulose. The characterization results of the palm midrib powder are shown in Table 1.

Table 1. Characteristic of palm midrib powder

\begin{tabular}{lc}
\hline \multicolumn{1}{c}{ Characteristic } & Content \\
\hline Water Content $(\%$ w.b) & 7.51 \\
Ash Content $(\%$ d.b) & 2.95 \\
Cellulose Content $(\%$ d.b) & 70.78 \\
\hline
\end{tabular}

In this study, comparison difference was observed. Palm midrib had a moisture content of $9.7 \%$ (d.b) and cellulose content of $35.88 \%$ (d.b) (Caesari et al., 2014). The difference in the characteristics of oil palm midrib occurred due to differences in the place of growth and varieties of oil palm. The chemical composition of palm midrib depended on the nutrient content of the plant and the absorptive properties of the plant.

\subsection{Effect of $\mathrm{NaOH}$ concentration on water content of cellulose}

The cellulose extracted from palm midrib had an average water content of $8 \%-9 \%$ (w.b). Figure 1 shows that the cellulose extracted using $15 \% \quad \mathrm{NaOH}$ concentration had the highest water content of $9.3 \%$ (w.b). But the results of statistical analysis showed that the concentration of $\mathrm{NaOH}$ did not affect the water content of cellulose.

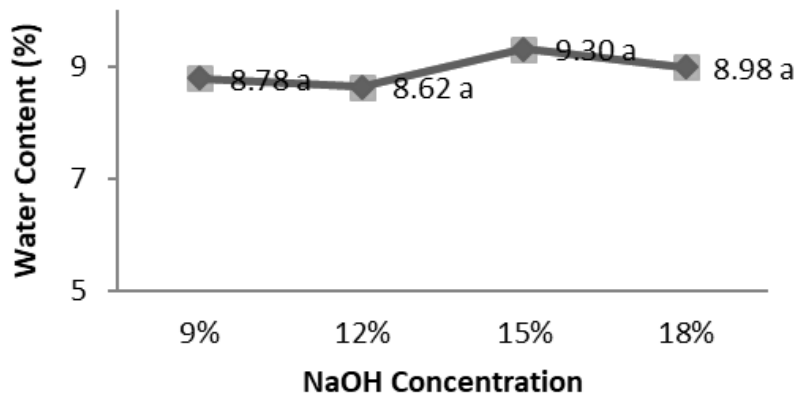

Figure 1. Effect of $\mathrm{NaOH}$ concentration on water content of cellulose

\subsection{Effect of $\mathrm{NaOH}$ concentration on yield of cellulose}

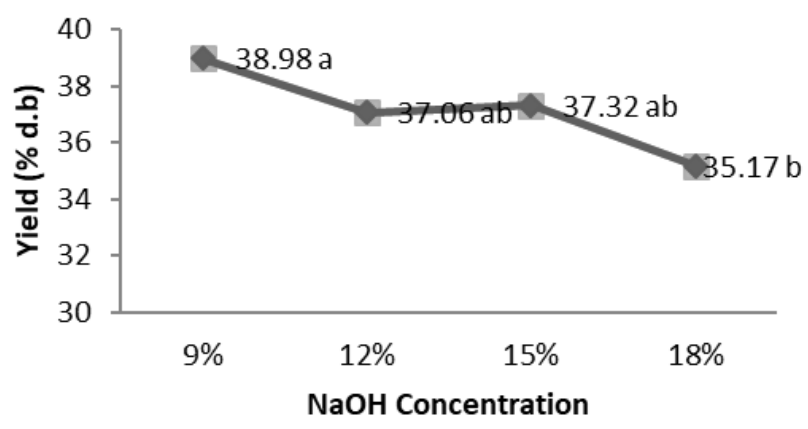

Figure 2. Effect of $\mathrm{NaOH}$ concentration on yield of cellulose

Increasing the $\mathrm{NaOH}$ concentration caused the yield to decrease in the process of cellulose extraction from palm midrib. The decrease in yield of the cellulose powder occurred due to $\mathrm{NaOH}$ breaks the lignin structure that bound cellulose fibers and dissolve them to pulp form, thus reducing the lignin. Brodeur et al. (2011) stated $\mathrm{NaOH}$ had been extensively studied for many years, and it had been shown to disrupt the lignin structure of the biomass, increasing the accessibility of enzymes to cellulose However, the decrease of the cellulose yield with increasing $\mathrm{NaOH}$ concentration may 
cause the increase of the cellulose purity when the lignin component is reduced. The effect of $\mathrm{NaOH}$ concentration on cellulose yield on palm midrib cellulose powder is displayed in Figure 2.

\subsection{Effect of $\mathrm{NaOH}$ concentration on cellulose content}

Different concentrations of $\mathrm{NaOH}$ also affected cellulose content, where increased $\mathrm{NaOH}$ concentration led to elevated cellulosic content. This was due to the increased ability of $\mathrm{NaOH}$ to break the lignocellulose bond so that cellulose will be free from lignin. The highest cellulose content was at the concentration of $15 \%$ $\mathrm{NaOH}$. However, concentration of $18 \% \mathrm{NaOH}$ tend to decrease cellulose content due to $\mathrm{NaOH}$ degrades cellulose by damaging the structural crystals of cellulose. The use of an alkali causes the degradation of ester and glycosidic side chains resulting in structural alteration of lignin, cellulose swelling, partial decrystallization of cellulose, and partial solvation of hemicellulose (Brodeur et al., 2011). The effect of $\mathrm{NaOH}$ concentration on cellulose content on palm midrib cellulose powder is shown in Figure 3.

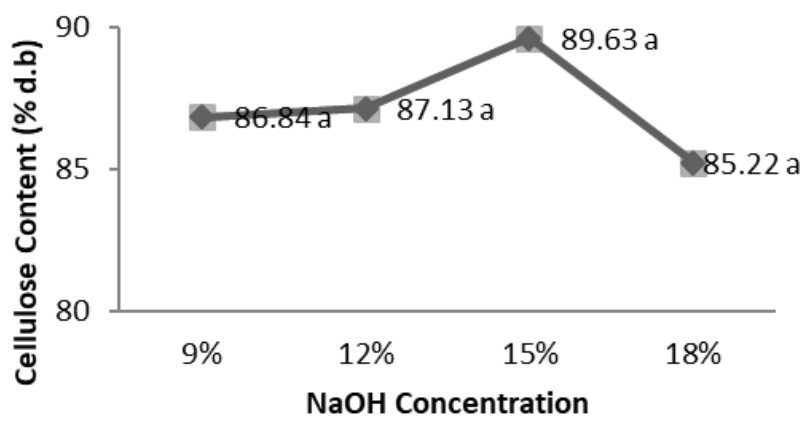

Figure 3. Effect of $\mathrm{NaOH}$ concentration on cellulose content

\subsection{Effect of $\mathrm{NaOH}$ concentration on cellulose lightness}

The $\mathrm{NaOH}$ concentration affected the lightness of the extracted cellulose with the pattern as shown in Figure 4. The higher concentration of $\mathrm{NaOH}$ led to the increase of lightness caused by the ability of $\mathrm{NaOH}$ to break the bond between cellulose with lignin. The noncellulose compounds cause the brown color of the material (Fengel and Wegener, 1995). The decrease in lightness at higher $\mathrm{NaOH}$ concentrations was due to the high concentration of the base of the solution so that the pigment removal process in the cellulose fiber was inhibited (Kuntari, 2006). Extremely high $\mathrm{NaOH}$ concentration caused the process of saturation, so the removal process of lignin was not optimal. Figure 5 shows the visual appearance of cellulose.

\subsection{Effect of $\mathrm{NaOH}$ concentration on cellulose crystallinity}

The crystallinity change occurring in the polymer was affected by the extraction conditions such as the $\mathrm{NaOH}$ concentration. Figure 6 showed the effect of
$\mathrm{NaOH}$ concentration on cellulose crystallinity. The higher $\mathrm{NaOH}$ concentration caused the crystallinity to decrease. Crystallinity decreases due to the intermittent hydrogen bonds and intra-molecules of cellulose due to the extraction process with $\mathrm{NaOH}$. As a result, the amorphous regions become more than the crystalline regions, so the percent crystallinity reduced. Cellulose with low crystallinity levels will be easier to process into cellulose derivative products.

The crystallinity of palm midrib cellulose extracted with $15 \% \mathrm{NaOH}$ was $31.57 \%$. Based on the previous research conducted by Adinugraha et al. (2005), the authors stated that $\mathrm{NaOH}$ influence on cellulose crystallinity. Other research mentioned banana stem cellulose extracted using $\mathrm{NaOH} 8 \%$ had a crystallinity of 49.27\% (Adinugraha et al., 2005), pineapple crown cellulose extracted using $12 \% \mathrm{NaOH}$ had a crystallinity of $36 \%$ (Suzana, 2009), pod husk cacao cellulose extracted using $12 \% \mathrm{NaOH}$ had a crystallinity of $27.14 \%$ (Hutomo et al., 2012), and water hyacinth cellulose extracted using $15 \% \mathrm{NaOH}$ had a crystallinity of $24.36 \%$ (Ventola, 2013).

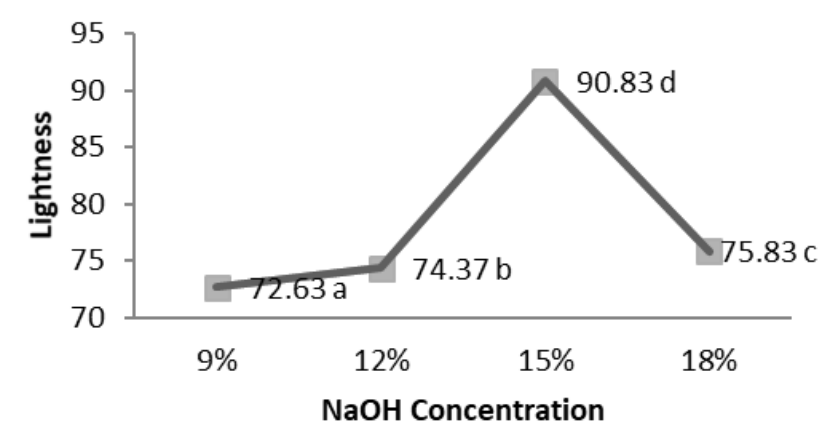

Figure 4. Effect of $\mathrm{NaOH}$ concentration on cellulose lightness

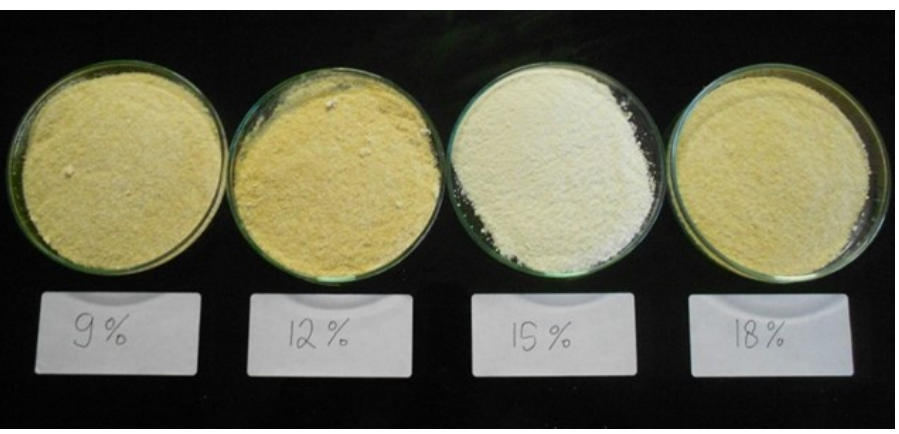

Figure 5. Cellulose powder extracted with various cancentrations of $\mathrm{NaOH}$

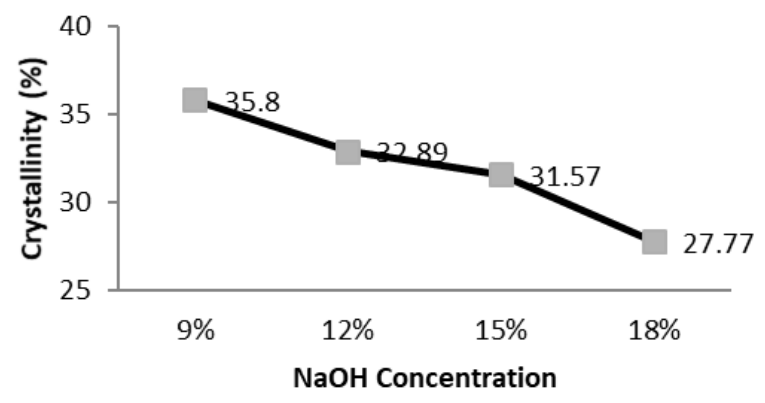

Figure 6. Effect of $\mathrm{NaOH}$ concentration on cellulose crystallinity

C 2018 The Authors. Published by Rynnye Lyan Resources 


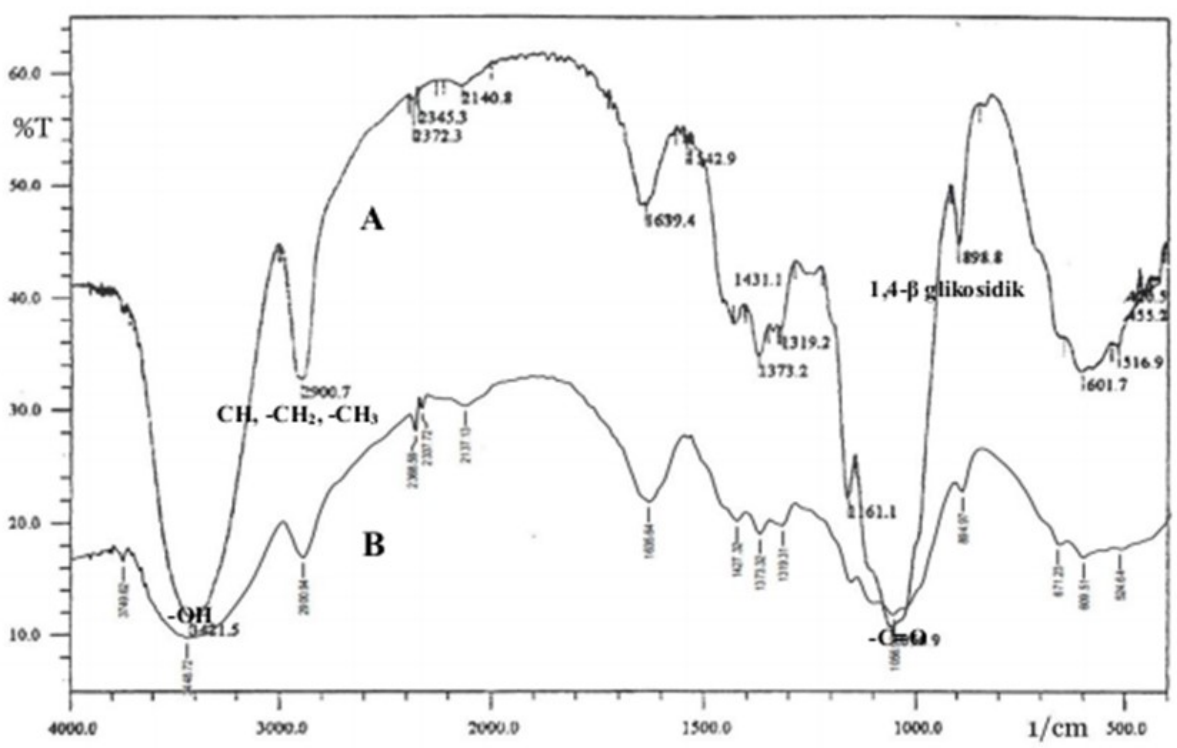

Figure 7. FTIR spectra of commercial cellulose (A) and palm midrib cellulose (B)

\subsection{FTIR spectra of cellulose}

The results of FTIR spectra of Sigma commercial cellulose and palm midrib cellulose that extraction with $15 \% \mathrm{NaOH}$ showed the same pattern. The $-\mathrm{OH}$ group will appear as an in-plane deformation at the wave number between $3,448-3,410 \mathrm{~cm}^{-1}$ where in the $\mathrm{OH}$ group of cellulose derived from palm midrib in a wave of $3,448.72 \mathrm{~cm}^{-1}$ (Meenakshi et al., 2002). The C-O group as stretching vibration was indicated on the wave number $1,064-1,056 \mathrm{~cm}^{-1}$, on the palm midrib cellulose peak at the wave number $1,056.99 \mathrm{~cm}^{-1}$. At the number of 3,448 $\mathrm{cm}^{-1}$ wave looks very sharp peak which was characteristic of cellulose. The peak shows stretching vibration and hydrogen bonds intra-molecular - $\mathrm{COH}$. The wave number $2,924-2,893 \mathrm{~cm}^{-1}$ was the peak of the $-\mathrm{CH}$ and $-\mathrm{CH}^{2}$ groups of cellulose. The wave number $894 \mathrm{~cm}^{-1}$ shows a 1.4- $\beta$ bond of cellulose. The results of commercial cellulose FTIR spectra and palm midrib cellulose can be seen in Table 2. FTIR spectra for commercial cellulose Sigma and palm midrib cellulose with $15 \% \mathrm{NaOH}$ is as shown in Figure 7 . The $15 \%$ $\mathrm{NaOH}$ concentration was the best treatment. It was based on the parameters of high lightness levels as a result of the double bleaching process.

Table 2. The results of FTIR spectra of commercial cellulose sigma and palm midrib cellulose

\begin{tabular}{ccl}
\hline \multicolumn{2}{c}{ Numbers of waves $\left(\mathrm{cm}^{-1}\right)$} & \\
\cline { 1 - 2 } $\begin{array}{c}\text { Sigma } \\
\text { Commercial } \\
\text { Cellulose }\end{array}$ & $\begin{array}{c}\text { Cellulose } \\
\text { Oil Palm }\end{array}$ & \multicolumn{1}{c}{ Cluster of Bonds } \\
\hline 3421 & 3448 & OH stretching \\
2900 & 2900 & CH streching $\mathrm{CH}_{2} \& \mathrm{CH}_{3}$ group \\
1373 & 1373 & OH inplane bonding \\
1056 & 1056 & C-O asymmetry bridge bonding \\
898 & 894 & $1,4-\beta$ glycosidic \\
\hline
\end{tabular}

\section{Conclusion}

The concentration of $\mathrm{NaOH}$ influenced the water content, cellulose content, yield, lightness, functional groups, and crystallinity of cellulose powder extracted from palm midrib. Cellulose powder extracted with $\mathrm{NaOH} 15 \%$ had water content $9.3 \%$ (w.b), cellulose content $89.63 \%$ (d.b), yield $37.32 \%$ (d.b), lightness value 90.83 , and crystallinity $31.57 \%$. NaOH had the ability to break lignocellulose bond so that cellulose will be released from lignin. The results of spectra FTIR analysis of commercial cellulose and cellulose from palm midrib extracted with $\mathrm{NaOH} 15 \%$ solution showed the same pattern of functional group.

\section{References}

Adinugraha, M.P., Marseno, D.W. and Haryadi. (2005). Synthesis and characterization of sodium carboxymethylcellulose from cavendish banana pseudo stem (Musa cavendishii LAMBERT). Carbohydrate Polymers, 62(2), 164-169. https:// doi.org/10.1016/j.carbpol.2005.07.019

ASTM. (1994). Standard Test Methods for Sodium Carboxymethylcellulose (ASTM: D1439-94), p. 291 -298. Philadelphia: ASTM Committee on Standards.

Brodeur, G., Yau, E., Badal, K., Collier, J., Ramachandran, K.B. and Ramakhrisnan, S. (2011). Chemical and Physicochemical Pretreatment of Lignocellulosic Biomas: A Review. Enzyme Research, $2011 . \quad$ http:// dx.doi.org/10.4061/2011/787532

Browning, B.L. (1967). Methods of wood chemistry. Vol 2, p. 387-427. New Jersey: Interscience Publishers, John Wiley and Sons.

Caesari., Padiln. and Yemilda. (2014). Pemurnian selulosa alfa pelepah kelapa sawit menggunakan 
enzim xylanase (In Bahasa Indonesia). Jurnal Online Mahasiswa, 1 (1), 1-8

Fengel, D. and Wegener, G. (1995). Wood: chemistry, ultrastructure, reactions. Yogyakarta: Gadjah Mada University Press.

Ferdiansyah, M.K., Marseno, D.W. and Pranoto, Y. (2017). Optimization of carboxy methyl cellulose (CMC) synthesis from palm midrib using response surface methodology (RSM). Agritech, 37(2), 158164. https://doi.org/10.22146/agritech.25363

Hutomo, G.S., Djagal, W.M., Anggrhini. and Supriyanto. (2012). Identification and characterization cellulose from pod husk cacao (Theobroma cacao L). Agritech, 32(3), 223229.

Kuntari. (2006). Optimalisasi proses desizing, scouring, bleaching, dan cautisizing secara simultan, sistem pad-batch pada kain rayon viskosa (In Bahasa Indonesia). Jurnal Sains Materi Indonesia, 2006, 118-123

Lii, C., Tomasik, P., Zaleska, H., Liauw, H. and Lai, V.M.F. (2002). Carboxymethylcellulose - gelatin complexes. Carbohydrate Polymers, 50(1), 19-26. https://doi.org/10.1016/S0144-8617(01)00372-1

Meenakshi, P., Noorjahan, S.E., Rajini, R., Venkateswarlu, U., Rose, C. and Sastry, T.P. (2002). Mechanical and microstucture studies on the modification of CA film by blending with PS. Bulletin of Material Science, 25 (1), 25-29. https:// doi.org/10.1007/BF02704590

Rossel, C.M., Santos, E. and Collar, C. (2009). Physicochemical properties of commercial fibers from different sources : A Comparative Approach. Food Research International, 42, 176-184. https:// doi.org/10.1016/j.foodres.2008.10.003

Sebayang, F. and Sembiring, H. (2017). Synthesis of CMC from palm midrib cellulose as stabilizer and thickening agent in food. Oriental Journal of Chemistry, 33(1), 519-530. https://doi.org/10.13005/ ojc/330162

Suzana. (2009). Synthesis and characterization of sodium carboxymethylcellulose from pineapple crown. Yogyakarta: Universitas Gadjah Mada, MSc. Thesis.

Ventola, S.C. (2013). Isolation of cellulose and carboxymethylcellulose (CMC) synthesis from water hyacinth. Yogyakarta: Universitas Gadjah Mada, MSc. Thesis. 